\title{
Fast protocol for extraction of DNA from Prosopis spp leaves (plant adapted to arid environment) without liquid nitrogen
}

\author{
C.Y. Michel-López, D. González-Mendoza and O. Grimaldo-Juarez \\ Instituto de Ciencias Agrícolas, Universidad Autónoma de Baja California, \\ Baja California, México \\ Corresponding author: D. González-Mendoza \\ E-mail: daniasaf@gmail.com
}

Genet. Mol. Res. 12 (3): 4090-4094 (2013)

Received September 14, 2012

Accepted January 31, 2013

Published September 27, 2013

DOI http://dx.doi.org/10.4238/2013.September.27.10

\begin{abstract}
The extraction of high-quality genomic DNA from Prosopis spp for polymerase chain reaction (PCR) amplification is complicated, owing to the presence of a high percentage of secondary metabolites that bind to or co-precipitate with nucleic acids. In the present study, we report a modified sodium dodecyl sulfate/phenol protocol that eliminates the use of liquid nitrogen in the maceration process, $\beta$-mercaptoethanol in the buffer extraction, and the ethanol precipitation step. The $\mathrm{A}_{260} / \mathrm{A}_{280}$ absorbance ratios of the isolated DNA were approximately 2.0 to 1.9 , suggesting that the DNA fraction was pure and can be used for further PCR analysis. The DNA isolated by this protocol is of sufficient quality for molecular applications; this technique could be applied to other organisms that have similar substances that hinder DNA extraction. Finally, this proposal represents an alternative fast, cheap, and effective method for the isolation of genomic DNA from fresh leaves of Prosopis spp, even in low-technology laboratories.
\end{abstract}

Key words: Genomic DNA extraction; Polymerase chain reaction; Prosopis spp 


\section{INTRODUCTION}

The term "mesquite" includes all leguminous trees of the genus Prosopis, of which nine species are found in the highly arid environments of Mexico (Rzedowski, 1988). In this sense, Prosopis glandulosa species are highly recognized for their properties as windbreakers, soil binders, and sand stabilizers, as well as their ability to grow in the poorest soils and to survive in areas where others trees cannot survive (Pasiecznik et al., 2001; Babiker-Hamza, 2010). In the Mexicali Valley, which is contiguous with the Imperial Valley in southern California, is a desert environment where P. glandulosa is widely distributed (Fredrickson et al., 2006). In recent years, uses of Prosopis spp in the bioremediation process have been reported. In this regard, Armienta et al. (2008) reported that mesquites are not hyperaccumulators, but are in fact As-tolerant plants and can therefore be considered as an option for a remediation program to stabilize eroding tailings. On the other hand, Haque et al. (2008) mentioned that mesquite plants have developed a variety of physiological and molecular mechanisms for growth in, and adaptation to, arid zones. These characteristic make mesquite plants a good candidate for studying the molecular mechanisms of tolerance to potentially toxic elements. However, Prosopis spp possess several alkaloids and other secondary metabolites, which may make their DNA unusable for downstream work in molecular biology research (Nakano et al., 2004). Presently, there are different protocols available for the isolation of genomic DNA from plants (Puchooa, 2004; Sarwat et al., 2006). Although the quantity and quality of DNAs obtained by these methods are generally satisfactory, these protocols are not universally applicable to all plants (e.g., Prosopis spp). Additionally, although some reported methods have minimized the DNA extraction steps, they still need a large amount of plant tissue, lysis steps, and liquid nitrogen (Tussell et al., 2005).

Therefore, the objective of this study was to develop a rapid protocol for the isolation of good-quality total DNA from $P$. glandulosa for implementation in molecular biology techniques, such as gene isolation by the polymerase chain reaction (PCR).

\section{MATERIAL AND METHODS}

\section{Vegetal material}

Fresh leaves of P. glandulosa were collected from the Mexicali Valley in Baja California, Mexico. The leaves were placed in a $1.5-\mathrm{mL}$ microtube and transferred to the laboratory without the need to be placed on ice and without making use of liquid nitrogen for the initial grinding of the tissue.

\section{DNA extraction buffer and solutions}

The tubes and bottles were treated with $0.1 \%$ diethylpyrocarbonate (DEPC) solution at $37^{\circ} \mathrm{C}$ overnight, autoclaved twice at $121^{\circ} \mathrm{C}$ for $20 \mathrm{~min}$, and then dried at $100^{\circ} \mathrm{C}$ before use. The extraction buffer was $2.5 \%$ sodium dodecyl sulfate (SDS) (w/v) containing $0.5 \mathrm{mM}$ EDTA and $0.1 \mathrm{mM}$ hydroxymethyl-hydrochloride (Tris-HCl, pH 8.0). A 1:1 (v/v) combination of chloroform-phenol was also prepared. 


\section{DNA extraction procedure}

About $200 \mathrm{mg}$ leaf sample was ground with $0.3 \mathrm{~mL}$ extraction buffer for $30 \mathrm{~s}$ (Figure 1). Then, $0.2 \mathrm{~mL}$ was transferred to a $1.5-\mathrm{mL}$ microcentrifuge tube, $0.2 \mathrm{~mL}$ chloroform-phenol mix was slowly added, and the tube was then incubated at $65^{\circ} \mathrm{C}$ for $5 \mathrm{~min}$. After incubation, the mixture was centrifuged at $11,000 \mathrm{~g}$ at $4^{\circ} \mathrm{C}$ for $5 \mathrm{~min}$. The supernatant $(80 \mu \mathrm{L})$ was transferred to a new microtube, and a 1-fold volume of cold absolute isopropanol was added and mixed thoroughly at $-20^{\circ} \mathrm{C}$ for $30 \mathrm{~min}$ for precipitating the total DNA; the mixture was then centrifuged at $11,000 \mathrm{~g}$ for $10 \mathrm{~min}$ at $4^{\circ} \mathrm{C}$. The supernatant was discarded, and the pellet was resuspended in $0.03 \mathrm{~mL}$ DEPC-treated MiniQuantum (deionized) water and stored at $-20^{\circ} \mathrm{C}$ for further use. The concentration, yield, and quality control indices such as $\mathrm{A}_{260} / \mathrm{A}_{280}$ and $\mathrm{A}_{260} /$ $\mathrm{A}_{230}$ ratios were determined with $5 \mu \mathrm{L}$ resuspended total DNA using a UV-Vis spectrophotometer. Total DNA solution $(5 \mu \mathrm{L})$ was loaded onto a $1 \%$ agarose gel, which was stained with ethidium bromide and electrophoresed to visualize the DNA under UV light.
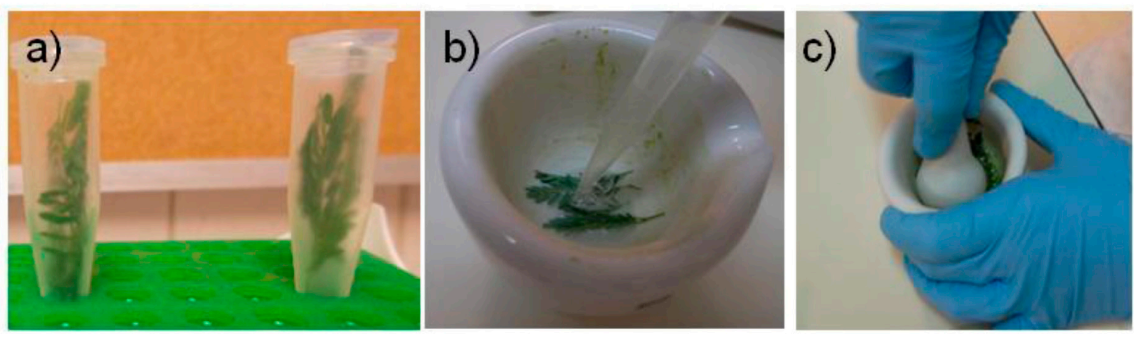

Figure 1. Fresh leaves of Prosopis glandulosa collected in 1.5-mL microtube (a), leaf with extraction buffer (b), and homogenization using a mortar and pestle without nitrogen (c).

\section{PCR}

Specific DNA was amplified by PCR with Taq DNA polymerase according to the manufacturer protocols (Fermentas). The PCR analysis was performed according to the method described by González-Mendoza et al. (2008), where $2 \mu$ L DNA (20 ng) was used as the PCR template. The PCR were performed using the $18 \mathrm{~S}$ rRNA from Ambion ${ }^{\circledR}$ as an internal control. The polymerase chain reactions were carried out using the following protocol: $95^{\circ} \mathrm{C}$ for $5 \mathrm{~min}(1 \mathrm{cycle}) ; 55^{\circ} \mathrm{C}$ for $40 \mathrm{~s}$ and $72^{\circ} \mathrm{C}$ for $1 \mathrm{~min}(35 \mathrm{cycles})$. The quality of the PCRs was determined by running the samples on a $1.5 \%$ Tris-acetate-EDTA-agarose gel and visualizing the bands after staining the gel with ethidium bromide. Images were captured and stored with the Multidoc-It Digital Imaging system (UVP).

\section{RESULTS AND DISCUSSION}

Prosopis spp are arid trees with high levels of polysaccharides, phenolics, and other organic constituents and metabolites that have medicinal properties and are used in foods and pharmaceuticals (Rathore, 2009). However, the presence of other alkaloids, tannins, and flavonoids could be responsible for the absence of nucleic acids during DNA extraction from these trees, since phenolic metabolites bind to and oxidize DNA irreversibly (Hassan et al., 2007). 
In the present study, we adapted a rapid RNA isolation method from fungus (GonzálezMendoza et al., 2008), combining an SDS extraction buffer without $\beta$-mercaptoethanol, and leaf homogenization using a mortar and pestle without liquid nitrogen. In this study, we also found that our procedure has the dual advantages of employing small amounts of buffer $(0.3$ $\mathrm{mL}$ ) and negating the step of pellet washing with $75 \%$ ethanol that would otherwise produce poor results and was therefore eliminated. Our results showed good yields of high-quality genomic DNA (Figure 2). The $\mathrm{A}_{260} / \mathrm{A}_{280}$ and $\mathrm{A}_{260} / \mathrm{A}_{230}$ ratios were $2.0 \pm 0.25$ and $1.70 \pm 0.38$, respectively, suggesting that the DNA fraction was pure and may be used for further PCR analysis. To confirm the DNA's purity and its use for basic molecular analysis, we PCR-amplified a fragment of the $18 \mathrm{~S}$ gene in Prosopis leaves. In this regard, the PCR amplification produced a single band of approximately $300 \mathrm{bp}$ specific to the $18 \mathrm{~S}$ gene (Figure 3 ).

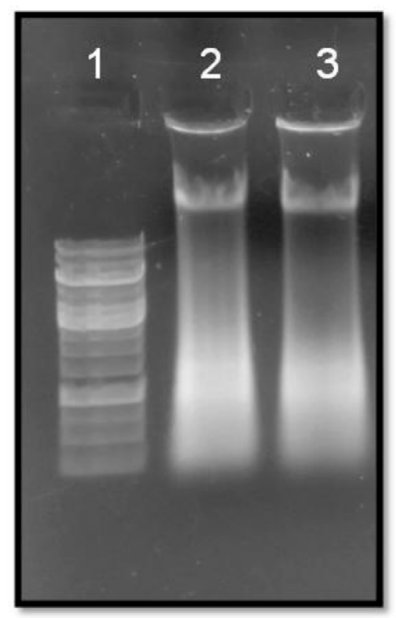

Figure 2. Gel electrophoresis of the total DNA extracted from Prosopis glandulosa. Lane 1 = DNA marker; lanes 2 and $3=$ DNA isolated from P. glandulosa .

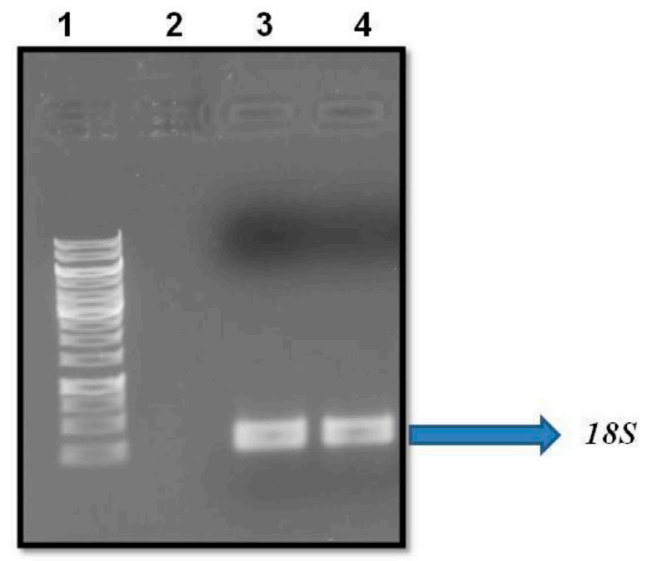

Figure 3. Agarose electrophoresis of the RT-PCR products. Lane 1 = DNA marker; lane 2 = negative control; lanes 3 and $4=300$-bp $18 S$ gene. 
The advantages of this procedure are that the DNA extraction may be realized in the absence of nitrogen liquid, and $\beta$-mercaptoethanol is not required as a reducing agent for removing tannins in the DNA extraction buffer. Additionally, this proposal represents an alternative fast, cheap, and effective method for the isolation of genomic DNA from fresh leaves of Prosopis, which is known to be a complicated species for the isolation of DNA, owing to the presence of a high percentage of secondary metabolites in these species.

\section{ACKNOWLEDGMENTS}

Research supported by the 15th Convocatoria Interna de Apoyo a Proyectos de Investigación de la Universidad Autónoma de Baja California and CONACYT (\#266972).

\section{REFERENCES}

Armienta MA, Ongley LK, Rodríguez R, Cruz O, et al. (2008). Arsenic distribution in mesquite (Prosopis laevigata) and huizache (Acacia farnesiana) in the Zimapán mining area, México. Geochem. Explor. Environ. Anal. 8: 191-197.

Babiker-Hamza N (2010). Genetic variation within and among three invasive Prosopis juliflora (Leguminosae) populations in the River Nile State, Sudan. Int. J. Genet. Mol. Biol. 2: 92-100.

Fredrickson EL, Estell RE, Laliberte A and Anderson DM (2006). Mesquite recruitment in the Chihuahuan Desert: historic and prehistoric patterns with long-term impacts. J. Arid Environ. 65: 285-295.

González-Mendoza D, Moreno AQ and Zapata-Perez O (2008). An improved method for the isolation of total RNA from Avicennia germinans leaves. Z. Naturforsch. C 63: 124-126.

Haque N, Peralta-Videa JR, Jones GL, Gill TE, et al. (2008). Screening the phytoremediation potential of desert broom (Baccharis sarothroides Gray) growing on mine tailings in Arizona, USA. Environ. Pollut. 153: 362-368.

Hassan SW, Umar RA, Ladan MJ, Nyemike P, et al. (2007). Nutritive value, phytochemical and antifungal properties of Pergularia tomentosa L. (Asclepiadaceae). Int. J. Pharmacol. 3: 340.

Nakano H, Nakajima E, Hiradate S, Fujii Y, et al. (2004). Growth inhibitory alkaloids from mesquite (Prosopis juliflora (Sw.) DC.) leaves. Phytochemistry 65: 587-591.

Pasiecznik NP, Felker P, Harris L, Harsh G, et al (2001). The Prosopis juliflora-Prosopis pallid Complex: A Monograph. Henry Doubleday Research Association, Coventry, 162.

Puchooa D (2004). A simple, rapid and efficient method for the extraction of genomic DNA from lychee (Litchi chinensis Sonn). Afr. J. Biotechnol. 3: 253-255.

Rathore M (2009). Nutrient content of important fruit trees from arid zone of Rajasthan. J. Hortic. For. 1: 103-108.

Rzedowski J (1988). Análisis de la distribución geográfica del complejo Prosopis (Leguminosae, Mimosoideae) en Norte América. Acta Bot. Mex. 3: 7-19.

Sarwat M, Negi MS, Lakshmikumaran M, Tyagi AK, et al. (2006). A standardized protocol for the genomic DNA isolation from Terminalia arjuna for genetic diversity analysis. Electron. J. Biotechnol. 9: 86-91.

Tapia-Tussell R, Quijano-Ramayo A, Rojas-Herrera R, Larque-Saavedra A, et al. (2005). A fast, simple, and reliable highyielding method for DNA extraction from different plant species. Mol. Biotechnol. 31: 137-139. 